\title{
UJI SITOTOKSITAS DAN ANTIPROLIFERATIF SEL KANKER PAYUDARA T47D DAN SEL VERO BIJI Nigella sativa, L.
}

\section{CYTOTOXICITY AND ANTIPROLIFERATIVE TEST ON T47D AND VERO CELL LINES OF Nigella sativa, L SEED}

\author{
Laela Hayu Nurani \\ Farmasi Universitas Ahmad Dahlan \\ Jl. Prof Dr. Supomo, Yogyakarta, Telp. (0274) 379418
}

\begin{abstract}
Abstrak
Biji jinten hitam mengandung golongan senyawa utama yaitu minyak atisiri, terpen, dan alkaloid yang dapat digunakan untuk pengobatan tradisional sebagai antikanker. Tujuan dari penelitian ini adalah untuk mengkaji efek sitotoksik ekstrak eter, etanol, dan infusa biji Nigella sativa, L. (jinten hitam) dalam hal kemampuannya menghambat pertumbuhan sel T47D dan normal (Vero) serta pengaruhnya terhadap kinetika proliferasi sel kanker payudara T47D. Dalam penelitian ini digunakan ekstrak eter, etanol, dan infusa biji jinten hitam yang diperoleh dengan metode maserasi dan infundasi. Uji sitotoksisitas dilakukan dengan menginkubasi sel kanker payudara T47D dengan kepadatan $2 \times 10^{4}$ dengan delapan seri kadar akhirnya yaitu 2000; 1000; 500; $250 ; 125 ; 62,5 ; 31,25$ dan 15,625 $\mu \mathrm{g} / \mathrm{ml}$ selama 24 jam. Sel Vero dengan kepadatan $2 x$ 10 dengan tujuh seri kadar yaitu 4000; 2000; 1000; 500; 250; 125 dan 62,5 $\mu \mathrm{g} / \mathrm{ml}$ diinkubasi selama 24 jam. Sebagai koreksi diujikan pula kontrol sel. Jumlah sel dihitung dengan metode perhitungan langsung dan dihitung persen kematiannya. Nilai $L C_{50}$ dihitung dengan menggunakan analisis probit. Pengamatan terhadap sifat penghambatan pertumbuhan dilakukan dengan mengamati kinetika proliferasi sel dengan penambahan biru tripan pada jam ke-24, 48 dan 72 untuk menentukan doubling time-nya. Hasil penelitian menunjukkan bahwa ekstrak eter, etanol, dan infusa biji jinten hitam bersifat sitotoksik terhadap sel kanker payudara T47D dengan
\end{abstract}


$L C_{50}$ berturut-turut sebesar 32,63; 10,02; dan 23,82 $\mu \mathrm{g} / \mathrm{mL}$. Uji sitotoksisitas terhadap sel Vero menghasilkan $L C_{50}$ berturut-turut sebesar 300,6; 328,41; dan 778, 64 $\mu \mathrm{g} / \mathrm{ml}$. Hasil uji antiproliferatif menunjukkan bahwa pada kadar 62,5 $\mu \mathrm{g} / \mathrm{ml}$ dan 31,625 $\mu \mathrm{g} / \mathrm{ml}$ memperpanjang doubling time. Ekstrak etanol biji jinten mempunyai potensi yang lebih besar karena mempunyai indeks keamanan yang paling besar dibandingkan ekstrak eter dan infusa.

Kata kunci : Biji Nigella sativa, L., sitotoksisitas, antiproliferatif, sel kanker payudara T47D, sel Vero.

\section{Abstract}

Black cumin seeds contain oil classes atisiri, terpenes, and alkaloids that can be used for traditional medicine as anticancer. The purpose of this study was to assess the cytotoxic effects of ether extract, ethanol, and infusa seed Nigella sativa, L. (Black cumin) to inhibit the growth of T47D and normal (Vero) cells and its effect on the kinetics of T47D breast cancer cells proliferation. This study were used extracts of ether, ethanol, and black cumin seeds infusa that obtained by maceration method and infundasi. Cytotoxicity test was performed by incubating T47D breast cancer cells at a $2 \times 104$ density with concentrations series of 2000; 1000; 500: 250: 125; 62.5; 31.25 and 15.625 microg/ml for 24 hours. Vero cell with a density of $2 \times 104$ with concentrations series of 4000; 2000; 1000; 500; 250; 125 and $62.5 \mathrm{microg} / \mathrm{ml}$. The number of cells was calculated by direct counting method and the calculated the death percentage. The LC50 values calculated using probit analysis. Observations on the nature of the growth inhibition were done by observing kinetics of cell proliferation with the addition of trypan blue at-24, 48 and 72 to determine its doubling time. The results showed that the ether extract, ethanol, and black cumin seeds infusa are cytotoxic to T47D breast cancer cells with successive LC50 of 32.63: 10.02, and 23.82 $m g$ mL. Vero cell cytotoxicity test to produce successive LC50 of 300.6; 328.41, and $778.64 \mathrm{~g} / \mathrm{ml}$. Antiproliferative test results showed that in $62.5 \mathrm{ug} / \mathrm{ml}$ and 31.625 microg/ml prolong the doubling time. Ethanol extract of cumin seeds have a higher potential due to the highest security index compared to ether extract and infusa.

Key words: Seeds of Nigella sativa, L., cytotoxicity, antiproliferative, T47D breast cancer cells, Vero cells. 


\section{PENDAHULUAN}

\section{Kanker adalah segolongan} penyakit yang ditandai dengan pembelahan sel yang tidak terkendali dan kemampuan sel-sel tersebut untuk menyerang jaringan biologis lainnya, baik dengan pertumbuhan langsung di jaringan yang bersebelahan (invasi) atau dengan migrasi sel ke tempat yang jauh (metastasis). Pertumbuhan yang tidak terkendali tersebut disebabkan kerusakan DNA, menyebabkan mutasi di gen vital yang mengontrol pembelahan sel. Beberapa buah mutasi mungkin dibutuhkan untuk mengubah sel normal menjadi sel kanker. Mutasi-mutasi tersebut sering diakibatkan agen kimia maupun fisik yang disebut karsinogen. Mutasi dapat terjadi secara spontan (diperoleh) ataupun diwariskan (mutasi germline) .

Etiologi tumor bervariasi dan umumnya masing-masing belum dapat dipastikan dengan jelas. Penyebab endogen, disamping adanya disposisi bawaan, ialah antara lain, terganggunya fungsi imun. Beberapa tumor pertumbuhannya akan dirangsang oleh hormon (misalnya pada karsinoma payudara oleh estrogen, pada karsinoma prostat oleh testosteron). Sebagai penyebab eksogen adalah sinar pengionisasi, karsinogen kimia dan virus onkogen .

Sifat umum dari kanker diantaranya adalah terjadi pertumbuhan berlebihan umumnya berbentuk tumor, adanya gangguan diferensiasi dari sel dan jaringan, bersifat invasive mampu tumbuh di jaringan sekitarnya (perbedaan pokok dengan jaringan normal), bersifat metastatis yaitu menyebar ke tempat lain dan menyebabkan pertumbuhan baru, memiliki hereditas bawaan (acquired heredity yaitu turunan sel kanker juga dapat menimbulkan kanker, terjadi pergeseran metabolisme ke arah pembentukan makromolekul dari nukleosida dan asam amino serta peningkatan katabolisme karbohidrat untuk energi sel . Salah satu jenis kanker yang mematikan adalah kanker payudara. Dua gen tumor mamma (BRCA-1 dan BRCA-2) diketahui bertanggung jawab atas diturunkannya kanker ini dari ibu ke anak perempuannya. Anak-anak yang membawa gen tersebut dalam kromosomnya berisiko amat tinggi untuk dihinggapi kanker mamma setelah usia 40 tahun .

Sel T47D memiliki karakteristik ER (Estrogen Reseptor)/PR (Progesteron Reseptor)-positif. Secara molekular sel mengalami mutasi pada p53, sehingga sel kehilangan kontrol pada regulasi cell cyclenya Sel Vero pertama kali diambil dari ginjal African Green Monkey dewasa pada tanggal 27 Maret 1967 oleh T. Yasamura dan T. Kawalata dari Universitas Chiba, Chiba Jepang .

Prinsip suatu tanaman dapat digunakan sebagai antikanker adalah apabila tanaman tersebut mengandung senyawa sitotoksik. Biji N. sativa, L. mengandung dua golongan senyawa utama yaitu terpen dan alkaloid dan juga mengandung sebagian kecil saponin. Terpen-terpen tersebut terutama adalah thymoquinone dan polimernya (seperti dithymoquinone), p-cimene dan á-pinene. Alkaloid yang banyak terdapat dalam biji $N$. sativa, $\mathrm{L}$. adalah nigellamine. Biji $N$. sativa, L. mengandung asam lemak tak jenuh, misalnya linoleic dan asam 
gammalinolen. Asam gammalinolen memungkinkan untuk pencapaian sintesis yang merupakan sistem kekebalan tubuh yang penting, yang meregulasi subtansi-subtansi yang merupakan turunan dari prostaglandin. Asam linoleic menstabilkan membran sel dan prostaglandin memiliki efek menghambat radang. Hal ini menghentikan reaksi kekebalan tubuh yang menyebabkan penyakit kronis seperti jerawat dan demam karena alergi hingga dapat menyebabkan kanker .

Untuk penyarian unsur aktif dari biji $N$. sativa, L. yang memiliki efek sebagai antitumor seperti thymoquinone, dithymoquinone, p-cimene, á-pinenenigellon, thymoquinon, asam lemak, digunakan cairan penyari eter. Senyawa-senyawa di atas bersifat polar sampai non polar sehingga perlu dilakukan penyarian dengan penyari dari air panas, etanol, dan eter. Sesuai dengan pernyataan like dissolve like yaitu suatu zat akan cenderung larut pada zat yang sama tingkat kepolarannya. Tujuan dari penelitian ini adalah mengetahui ekstrak yang mempunyai potensi sitotoksisitas paling besar terhadap sel T47D dan perbandingannya terhadap sel Vero. Dengan perbedaan senyawa yang tersari maka aktivitas dari masing-masing ekstrak akan mempunyai tingkatan sitotoksisitas yang berbeda.

\section{METODE PENELITIAN}

Alat-alat yang digunakan dalam penelitian ini terdiri dari, pengaduk elektrik (Erweka), corong Buchner, inkubator $\mathrm{CO}_{2}$ (Inc 2 Memmert), autoklaf, tangki nitrogen cair (Cryolab 35), alat-alat gelas steril, laminar air flow cabinet (LAF) (Lab Konko), mikroskop fase kontras (Olympus), tissue culture flask (Nunclone), blue tip, yellow tip, timbangan elektrik (Sartorius), mikropipet (Socorex), mikroplate 96 sumuran (Nunclone), mikrofilter 0,22 (Pall), ELISA reader (SLT), tabung conical $15 \mathrm{ml}$ (Nunclone), tissue culture cluster 96 (Nunclone), Haemocytometer.

Senyawa uji yang digunakan dalam penelitian ini adalah ekstrak eter, etanol, dan air biji $N$. sativa, L (jinten hitam). Sel yang digunakan dalam uji ini adalah sel kanker payudara T47D dan sel Vero. Bahan kimia yang digunakan FBS (Fetal Bovine Serum) 10\%, FBS 0,5\%, Media Kultur Medium RPMI (Rosewell Park Memorial Institute) 1640 (Gibco), media kultur Medium 199 (Gibco), Tripsin EDTA 0,25\%, PBS (Phosphat Buffer Saline), Fungison (Gibco), Penisilin Streptomisin 1\% $\mathrm{v} / \mathrm{v}$, aqua bidestilata, etanol $70 \%$, Natrium bikarbonat, HEPES (N-2-Hidroxy Ethyl Piperazine-N-Ethane Sulfonic acid), SDS (Sodium Dodecyl Sulphate) 10\% dalam $\mathrm{HCl} 0,01 \mathrm{~N}$, DMSO 0,5\%, biru tripan, eter, etanol, dan aquadest.

\section{Pembuatan media biakan dan penumbuh sel}

Pembuatan media biakan RPMI 1640 dan M199 adalah dengan melarutkan serbuk RPMI (Rosewell Park Memorial Institute) 1640 dan M199 untuk satu liter masing-masing ke dalam aquabidestilata kira-kira $800 \mathrm{ml}$, ditambah natrium bikarbonat 2,0 gram dan HEPES 2,0 gram, ditambahkan aqua bidestilata sampai 1 liter. Larutan diaduk dengan pengaduk magnetik sekitar 10 menit hingga homogen, lalu didapar dengan $\mathrm{HCl} 1 \mathrm{~N}$ hingga $\mathrm{pH} 7,2-7,4$. 
Media penumbuh sel dibuat dengan cara mencampurkan FBS sebanyak $10 \mathrm{ml}$, penisilin streptomisin 2 $\mathrm{ml}$, fungison $0,5 \mathrm{ml}$ kemudian diencerkan menggunakan media biakan masingmasing (RPMI 1640 dan M199) sampai $100 \mathrm{ml}$. Selanjutnya larutan disaring dengan filter polietilen sulfon steril 0,2 $\mu \mathrm{m}$ secara aseptis. Disimpan dalam lemari es dengan menggunakan botol steril tertutup.

\section{Pembuatan larutan uji}

Larutan stok dibuat dengan cara menimbang $50 \mathrm{mg}$ ekstrak eter, etanol, dan infusa biji $N$. sativa, L dilarutkan dalam $100 \quad \mu 1$ DMSO kemudian ditambahkan media (RPMI 1640 untuk sel kanker payudara T47D dan M199 untuk sel Vero) hingga $1000 \mu \mathrm{l}$. Larutan stok dimasukkan ke dalam eppendorf steril ditutup, dan disimpan dalam lemari es. Selanjutnya dibuat larutan dengan seri kadar $(4000,2000 ; 1000$; $500 ; 250 ; 125 ; 62,5 ;$ dan 31,25$) \mu \mathrm{g} / \mathrm{ml}$ (untuk sel kanker payudara T47D), dan larutan dengan seri kadar $(8000,4000$; $2000 ; 1000 ; 500 ; 250$; dan 125$) \mu \mathrm{g} / \mathrm{ml}$ (untuk sel Vero). Pembuatan larutan stok maupun seri kadar untuk perlakuan dilakukan secara aseptis di dalam LAF-cabinet.

\section{Preparasi sel}

Sel yang inaktif dalam wadah ampul diambil dari tangki nitrogen cair dan segera dicairkan pada suhu $37^{\circ} \mathrm{C}$. Ampul dibuka dan sel dipindahkan ke dalam tabung konikal steril yang berisi media masing-masing sel (RPMI 1640 untuk sel kanker payudara T47D, M199 untuk sel Vero). Suspensi sel disentri- fuge 2000 rpm selama 5 menit, kemudian bagian supernatan dibuang, endapan putih yang terdapat di dasar konikal adalah koloni sel. Setelah supernatan dibuang, diganti media yang baru kemudian disuspensikan perlahan. Suspensi sel disentrifuge lagi selama 5 menit, supernatan dibuang, pellet ditambah $1 \mathrm{ml}$ media penumbuh dengan FBS $10 \%$, diresuspensikan perlahan hingga homogen. Selanjutnya sel ditumbuhkan dalam beberapa tissue culture flask kecil (3-4 buah), diinkubasikan dalam inkubator suhu $37^{\circ} \mathrm{C}$ $\mathrm{CO}_{2} 5 \%$. Dilihat 2-3 hari, media diganti dan sel ditumbuhkan lagi hingga konfluen (sel telah memenuhi flask) dan jumlahnya cukup untuk penelitian.

\section{Panen sel}

Setelah jumlah sel cukup, media dibuang dan sel dicuci koloninya dengan cara ditambah larutan PBS dan jika perlu diresuspensikan perlahan, larutan tersebut dibuang, sel ditambah larutan tripsin EDTA 0,25\% sebanyak $3 \mathrm{ml}$, didiamkan selama sekitar 3-5 menit agar tripsin EDTA bekerja dengan baik. Logam-logam yang terdapat pada media akan berikatan dengan EDTA. Sel dipindah ke dalam tabung konikal steril dan ditambah PBS sampai volume $10 \mathrm{ml}$ dan disentrifuge $2000 \mathrm{rpm}$ selama 5 menit. Sel dicuci dua kali menggunakan media yang sama dan dihitung jumlah selnya menggunakan haemocytometer di bawah mikroskop.

Jumlah sel dihitung dengan cara:

$\frac{\text { Jumlah sel dalam } 4 \text { bilik x } 10^{4} \mathrm{sel} / \mathrm{ml}}{4}$

(Doyle and Griffiths, 2000) 
Jumlah sel yang telah diketahui kemudian dibuat enceran sel dengan kepadatan sel $2 \times 10^{4}$ sel per sumuran dengan media biakan.

\section{Uji sitotoksisitas}

Microplate dengan 96 sumuran diisi $100 \mu \mathrm{l}$ suspensi sel kanker payudara T47D dalam media RPMI 1640. Sampel $100 \mu$ ditambahkan ke dalam sumuran yaitu ekstrak eter, etanol, dan infusa biji N. sativa, L. kadar $(2000 ; 1000 ; 500$; $250 ; 125 ; 62,5 ; 31,25) \mu \mathrm{g} / \mathrm{ml}$ masingmasing dimasukkan ke dalam plate 96 sumuran yang berbeda. Selain sampel, dimasukkan juga kontrol sel. Kontrol sel pada sumuran terdiri dari $100 \mu \mathrm{l}$ media RPMI 1640.

Microplate dengan 96 sumuran diisi $100 \mu \mathrm{l}$ suspensi sel (kepadatan $2 \mathrm{x}$ $104 \mathrm{sel} /$ sumuran) dalam media M199. Sampel $100 \mu \mathrm{l}$ ditambahkan ke dalam sumuran yaitu ekstrak éter, etanol, dan infusa biji $N$. sativa, L. kadar (4000; 2000; 1000; 500; 250; 125) $\mathrm{mg} / \mathrm{ml}$ masing-masing dimasukkan ke dalam plate 96 sumuran yang berbeda. Selain sampel, dimasukkan juga kontrol sel. Kontrol sel pada sumuran terdiri dari 100 $\mu 1$ media M199. Volume akhir pada masing-masing sumuran adalan $200 \mu 1$ (100 $\mu$ l larutan uji $+100 \mu l$ suspensi sel). Pengujian sediaan uji dilakukan replikasi sebanyak tiga kali tiap kadar. Selanjutnya kultur sel diinkubasi dalam inkubator suhu $37^{\circ} \mathrm{C}$ dengan aliran 5\% $\mathrm{CO} 2$ selama 24 jam.

Untuk perhitungan, tiap sumuran ditambahkan tripsin-EDTA $100 \mu$ l. Setelah kurang lebih 3 menit, diresuspensi dan diambil untuk dihitung jumlah sel menggunakan haemocytometer di bawah mikroskop. Perhitungan jumlah sel hidup dilakukan dengan tripan blue. Sel yang mati akan menyerap warna tripan blue, sedangkan sel yang hidup tidak akan menyerap warna biru.

\section{Uji antiproliferatif}

Sel di-starvasi (dipuasakan) selama 24 jam dalam media kultur yang mengandung FBS 0,5\%. Selanjutnya sel ditumbuhkan dalam plate dengan medium dan larutan uji dengan seri kadar $(125 ; 62,5 ; 31,25) \mu \mathrm{g} / \mathrm{ml}$. Perlakuan sama seperti uji sitotoksisitas dengan menggunakan metode perhitungan langsung. Sampling dilakukan pada jam ke-0, 24, 48 dan 72 serta replikasi dilakukan sebanyak 3 kali. Masingmasing sampel dihitung dengan haemocytometer di bawah mikroskop. Dibuat kurva jumlah sel vs waktu inkubasi. Perbedaan waktu penggandaan sel (doubling time) dilihat dari slope yang dihasilkan dari kurva hubungan antara waktu inkubasi vx log jumlah sel hidup.

\section{HASIL DAN PEMBAHASAN}

Uji sitotoksisitas ekstrak eter, etanol, dan infusa biji N. sativa, L. terhadap sel kanker payudara T47D.

Uji sitotoksisitas dilakukan secara manual (perhitungan langsung) dengan menghitung jumlah sel hidup dibandingkan kontrol sel, dengan ekstrak eter, etanol, dan infusa biji $N$. sativa, L. kadar $(2000 ; 1000 ; 500 ; 250 ; 125 ; 62,5 ; 31,25)$ $\mu \mathrm{g} / \mathrm{ml}$ sebanyak 1001 ditambah sel kanker payudara T47D dengan kepadatan $2 \times 10^{4}$ dalam media RPMI 1640 
sebanyak 1001 . Untuk kontrol sel berisi 1001 media RPMI 1640.

Penetapan jumlah sel yang bertahan hidup pada uji sitotoksisitas ini dilakukan berdasarkan parameter kerusakan membran yang dilakukan menggunakan biru tripan. Jika sel kanker payudara T47D mati maka akan terjadi kerusakan membran, sehingga biru tripan akan masuk kedalam sel dan berikatan dengan protein sehingga sel yang mati akan tampak biru. Sel yang hidup karena membran plasmanya masih utuh maka protein dalam sel tidak akan berikatan (uptake) dengan biru tripan sehingga sel tampak terang bersinar. Morfologi sel kanker payudara T47D dalam sumuran dengan perlakuan ekstrak eter, etanol, dan infusa biji $N$. sativa, L. dan kontrol sel dapat dilihat pada Gambar 1.

Dari kurva hubungan antara log kadar dan probit sampel (Gambar 1) diperoleh LC50 ekstrak.
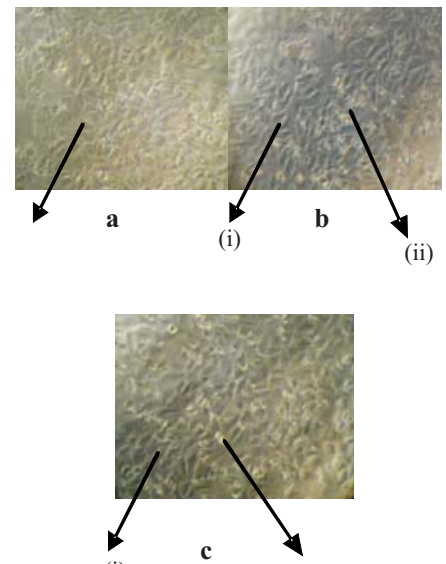

(ii)

Gambar 1. Morfologi sel kanker payudara T47D dalam sumuran dengan perlakuanekstrak biji $N$. sativa, L, sel hidup (i); sel mati (ii).

Harga $\mathrm{LC}_{50}$ didapat dengan memasukkan harga probit $=5$ (persen kematian 50\%) ke dalam persamaan, sehingga diperoleh harga LC50 ekstrak eter, etanol, dan infusa berturut-turut sebesar 32,63; 10,02; dan 23, $82 \mu \mathrm{g} / \mathrm{ml}$. Penentuan harga $\mathrm{LC}_{50}$ ini penting untuk mengetahui potensi ketoksikan ekstrak

Tabel 1. Hasil uji sitotosisitas ekstrak eter, etanol, dan infusa biji $N$. sativa, L. terhadap sel kanker payudara T47D dengan metode perhitungan langsung

\begin{tabular}{|c|c|c|c|c|c|c|c|}
\hline \multirow{2}{*}{$\begin{array}{c}\text { Kadar } \\
(\boldsymbol{\mu g} / \mathbf{m L})\end{array}$} & \multirow{2}{*}{$\begin{array}{c}\text { Log } \\
\text { kadar }\end{array}$} & \multicolumn{3}{|c|}{ \% kematian sel } & \multicolumn{3}{c|}{ Probit } \\
\cline { 3 - 8 } & E.Eter & E.EtOH & Infusa & E.Eter & E.EtOH & Infusa \\
\hline 1000 & 3,000 & 81,91 & 83,78 & 93,21 & 5,92 & 5,98 & 6,50 \\
\hline 500 & 2,698 & 72,85 & 77,03 & 78,73 & 5,61 & 5,77 & 5,80 \\
\hline 250 & 2,397 & 64,71 & 72,07 & 73,30 & 5,38 & 5,58 & 5,62 \\
\hline 125 & 2,097 & 58,37 & 66,22 & 66,06 & 5,21 & 5,42 & 5,41 \\
\hline 62,5 & 1,796 & 51,13 & 60,36 & 59,73 & 5,03 & 5,26 & 5,24 \\
\hline 31,25 & 1,495 & 44,79 & 53,15 & 51,13 & 4,87 & 5,10 & 5,03 \\
\hline 15,625 & 1,194 & 37,11 & 44,14 & 42,08 & 4,67 & 4,85 & 4,80 \\
\hline
\end{tabular}




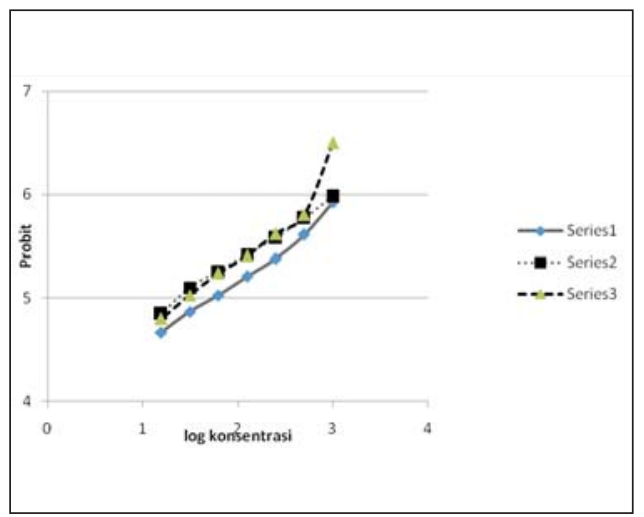

Gambar 2. Kurva hubungan antara log konsentrasi ekstrak eter, etanol, dan infusa vs probit

biji $N$. sativa, L. terhadap sel kanker payudara T47D. Uji selanjutnya adalah uji antiproliferatif. Uji antiproliferatif bermanfaat untuk melihat kinetika proliferasi sel kanker payudara T47D karena pemberian ekstrak eter, etanol, dan infusa biji $N$. sativa, L. dengan penekanan pada cell cycle progression dari sel kanker payudara T47D.

Uji sitotoksisitas terhadap sel T47D oleh pengaruh eksrak eter, etanol, dan infusa dilakukan dengan menginkubasi $2 \times 10^{4}$ sel T47D dengan kadar akhir ekstrak yaitu 1000; 1000; $500 ; 250 ; 125 ; 62,5 ; 31,25$ dan 15,625 $\mu \mathrm{g} / \mathrm{mL}$. Uji sitotoksisitas terhadap sel Vero dilakukan dengan menginkubasi 2 x $10^{4}$ sel Vero dengan kadar akhir ekstrak yaitu 2000; 1000; 500; 250; 125; 62,5 dan $31,25 \mu \mathrm{g} / \mathrm{mL}$. Penetapan jumlah sel yang masih bertahan hidup pada uji sitotoksisitas ini dilakukan dengan metode perhitungan langsung berdasarkan parameter kerusakan membran yang dilakukan menggunakan biru tripan. Jika sel T47D dan sel Vero mati maka akan terjadi kerusakan membran, sehingga biru tripan akan masuk ke dalam sel dan berikatan dengan protein sehingga sel yang mati akan tampak biru. Sel yang hidup karena membran plasmanya masih utuh maka protein dalam sel tidak akan berikatan dengan biru tripan sehingga sel kelihatan mengkilap.

Berdasarkan hasil $\mathrm{LC}_{50}$ yang diperoleh ekstrak etanol mempunyai potensi sitotoksik yang paling besar terhadap sel kanker T47D dibandingkan dengan ekstrak eter dan infusa. Hal ini karena polaritas senyawa dominan Nigella sativa lebih larut di dalam etanol.

\section{Uji ekstrak eter, etanol, dan infusa biji N sativa, L. terhadap sel Vero.}

Uji sitotoksisitas sel Vero dilakukan secara manual (perhitungan langsung) dengan menghitung jumlah sel hidup dibandingkan kontrol, dengan ekstrak eter, etanol, dan infusa biji $N$. sativa, L. kadar (4000; 2000; 1000; 500; $250 ; 125) \mu \mathrm{g} / \mathrm{ml}$ sebanyak 100 il ditambah sel Vero dengan kepadatan $2 \mathrm{x}$ 104 dalam media M199 sebanyak $100 \mathrm{il}$. Untuk kontrol sel berisi 100 il media M199. Penetapan jumlah sel yang bertahan hidup pada uji sitotoksisitas ini dilakukan berdasarkan parameter kerusakan membran yang dilakukan menggunakan biru tripan. Jika sel Vero mati maka akan terjadi kerusakan membran, sehingga biru tripan akan masuk kedalam sel dan berikatan dengan protein sehingga sel yang mati akan tampak biru. Sel yang hidup karena membran plasmanya masih utuh maka protein dalam sel tidak akan berikatan (uptake) dengan biru tripan sehingga sel tampak terang bersinar. Hasil persentase 
kematian sel karena pemaparan ekstrak dengan kadar tertentu terlihat pada Tabel 2 .
Hasil yang diperoleh sesuai harapan yaitu ekstrak eter, etanol, dan air biji $N$. sativa, L. yang bersifat sitoksik terhadap

Tabel 2. Hasil uji sitotoksisitas ekstrak eter, etanol, dan infusa biji N. sativa, L. terhadap sel Vero dengan metode perhitungan langsung

\begin{tabular}{|c|c|c|c|c|c|c|c|}
\hline \multirow{2}{*}{$\begin{array}{c}\text { Kadar } \\
(\mu \mathrm{g} / \mathrm{mL})\end{array}$} & \multirow{2}{*}{$\begin{array}{c}\text { Log } \\
\text { kadar }\end{array}$} & \multicolumn{3}{|c|}{$\%$ kematian sel } & \multicolumn{3}{|c|}{ Probit } \\
\hline & & E.Eter & E.EtOH & Infusa & E.Eter & E.EtOH & Infusa \\
\hline 2000 & 3,30 & 84 & 94,37 & 93,94 & 5,99 & 6,58 & 6,55 \\
\hline 1000 & 3 & 50,62 & 74,89 & 73,59 & 5,02 & 5,67 & 5,63 \\
\hline 500 & 2,69 & 32,78 & 54,11 & 51,08 & 4,55 & 5,12 & 5,03 \\
\hline 250 & 2,39 & 15,35 & 44,16 & 44,16 & 3,98 & 4,85 & 4,85 \\
\hline 125 & 2,09 & 8,29 & 31,60 & 31,60 & 3,61 & 4,53 & 4,52 \\
\hline 62,5 & 1,79 & 1,25 & 14,29 & 10,39 & 2,74 & 3,93 & 3,74 \\
\hline
\end{tabular}

Harga $\mathrm{LC}_{50}$ didapat dengan memasukkan harga probit $=5$ (persen kematian 50\%) ke dalam persamaan, sehingga diperoleh harga LC50 ekstrak eter, etanol, dan infusa berturut-turut sebesar 300,6; 328,41; dan 778,64 $\mu \mathrm{g} / \mathrm{ml}$. Hasil ini diperoleh dari persamaan garis dari kurva hubungan log kadar vs probit seperti terlihat pada Gambar 3.

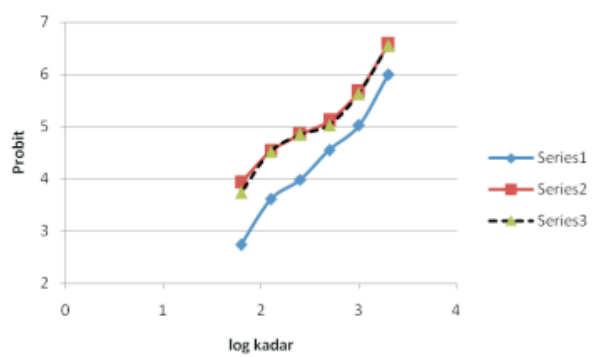

Gambar 3. Kurva hubungan antara log kadar ekstrak Nigella sativa terhadap probit sel Vero sel kanker payudara T47D namun pada kadar tersebut tidak menghambat perkembangan dari sel normal. Berdasarkan perbandingan antara LC50 ekstrak eter, etanol, dan infusa terhadap sel T47D dan sel Vero diperoleh harga keamanan yang paling besar adalah ekstrak etanol. Diharapkan ekstrak etanol biji $N$. sativa, L. dapat dikembangkan menjadi alternatif obat antikanker yang poten.

Uji antiproliferatif ekstrak eter, etanol, dan infusa biji $N$. sativa,L. terhadap sel kanker payudara T47D.

Tujuan uji antiproliferatif adalah untuk mengetahui kecepatan pertumbuhan sel dapat dipengaruhi oleh adanya pengaruh ekstrak eter biji $N$. sativa, L. terhadap kinetika proliferasi oleh adanya pengaruh lamanya inkubasi. Parameter yang digunakan pada uji ini adalah kecepatan sel untuk membelah menjadi 2 kali lipat pada tiap kadar yang 
dipakai. Kadar yang digunakan untuk uji antiproliferatif adalah $(62,5 ; 31,25$;

dengan metode perhitungan langsung dapat dilihat pada Tabel 3.

Tabel 3. Hasil uji antiproliferatif ekstrak eter biji N. sativa, L terhadap sel kanker payudara T47D dengan metode perhitungan langsung

\begin{tabular}{|l|l|l|l|l|l|l|}
\hline \multirow{2}{*}{ Kadar } & \multicolumn{3}{|l|}{ Jumlah sel hidup } & $\begin{array}{l}\text { Persamaan antara } \\
\text { waktu inkubasi vs } \\
\text { jumlah sel hidup }\end{array}$ & $\begin{array}{l}\text { Doublin } \\
\text { g time }\end{array}$ \\
\cline { 2 - 8 } & $\begin{array}{l}\text { Jam } \\
\text { ke-0 }\end{array}$ & $\begin{array}{l}\text { Jam } \\
\text { ke-24 }\end{array}$ & $\begin{array}{l}\text { Jam } \\
\text { ke-48 }\end{array}$ & $\begin{array}{l}\text { Jam } \\
\text { ke-72 }\end{array}$ & \\
\hline Kontrol, etanol & 20000 & 43333 & 90833 & 185333 & $\mathrm{Y}=0,013 \mathrm{x}+4,311$ & 22,38 \\
\hline 62,5 (E. Etanol) & 20000 & 28333 & 56333 & 112333 & $\mathrm{Y}=0,011 \mathrm{x}+4,256$ & 31,45 \\
\hline 31,25 (E. Etanol) & 20000 & 32333 & 66500 & 133500 & $\mathrm{Y}=0,012 \mathrm{x}+4,271$ & 27,58 \\
\hline 62,5 (E. Eter) & 20000 & 32500 & 64833 & 132666 & $\mathrm{Y}=0,012 \mathrm{x}+4,271$ & 27,59 \\
\hline 31,25 (E. Eter) & 20000 & 37500 & 74000 & 155500 & $\mathrm{Y}=0,012 \mathrm{x}+4,287$ & 26,26 \\
\hline 62,5 (Infusa) & 20000 & 26833 & 55333 & 112166 & $\mathrm{Y}=0,011 \mathrm{x}+4,248$ & 32,273 \\
\hline 31,25 (Infusa) & 20000 & 30166 & 65666 & 133500 & $\mathrm{Y}=0,012 \mathrm{x}+4,271$ & 28,583 \\
\hline
\end{tabular}

Keterangan: $\mathrm{E}=$ ekstrak

$15,625) \mu \mathrm{g} / \mathrm{ml}$ dan kontrol pelarut. Penghitungan sel dilakukan pada jam ke-0, 24, 48, dan 72. Uji antiproliferatif dilakukan dengan metode perhitungan langsung pada satuan waktu. Sebelumnya sel kanker payudara dipuasakan (starvasi) selama 24 jam dengan menggunakan media RPMI 1640 yang mengandung FBS 0,5\%. Pengurangan signal pertumbuhan ini diperlukan karena akan mengurangi kecepatan pertumbuhan sel yang menyebabkan sel akan berada dalam start awal yang sama yaitu pada fase G0. Tanpa dipuasakan saat diberi perlakuan sel-sel berada pada fase yang berbeda-beda sehingga akan menyulitkan pengamatan sifat penghambatan ekstrak eter biji $N$. sativa, L. pada cell cycle progression.

Hasil uji antiproliferatif ekstrak eter, etanol, dan infusa biji $N$. sativa, L terhadap sel kanker payudara T47D
Setelah jumlah sel hidup diketahui pada jam ke- 0, 24, 48 dan 72 kemudian ditentukan kemampuan penghambatan proliferasi sel. Efek antiproliferatif terhadap sel kanker payudara T47D dapat dianalisis dengan cara menghitung waktu yang diperlukan sel untuk menggandakan dirinya menjadi dua kali lipat (doubling time). Hasil kehidupan sel untuk kontrol sel, jumlah sel langsung mengalami peningkatan dan tidak menunjukkan adanya lag time. Lag time adalah waktu dimana jumlah sel relatif tetap karena sel sedang beradaptasi dengan lingkungan baru.

Berdasarkan hasil yang diperoleh, terlihat bahwa secara umum ekstrak eter, etanol, dan infusa mempunyai aktivitas penghambatan pertumbuhan sel T4D. Hal ini ditunjukkan oleh doubling time sel T47D pengaruh pemberian ekstrak yang lebih besar dibandingkan dengan kontrol (tanpa ekstrak). 
Semakin besar kadar sampel semakin panjang harga doubling time dan semakin kecil jumlah sel yang hidup. Hal ini disebabkan karena ekstrak etanol biji jinten hitam tidak cukup untuk membunuh semua sel sehingga sel yang masih hidup terus berproliferasi didukung tersedianya nutrisi dari media RPMI 1640. Hasil penelitian menunjukkan dengan kadar 62,5 dan 15,625 $\mu \mathrm{g} / \mathrm{mL}$ dapat menghambat aktivitas proliferasi sel T47D.

Secara umum profil pertumbuhan sel T47D pada perlakuan ekstrak etanol biji jinten hitam mengalami adanya penghambatan seperti tersaji dalam Tabel 2. Ini dibuktikan dengan profil perlakuan selalu di bawah kontrol. Harga waktu penghambatan (doubling time) perlakuan lebih besar dibanding dengan kontrol. Hal ini menunjukkan bahwa ekstrak etanol biji jinten hitam memiliki kemampuan untuk menghambat proliferasi sel T47D dan memiliki aktivitas sitotoksis. melaporkan bahwa biji jinten hitam mengandung karoten yang mampu melumpuhkan radikal bebas penyakit kanker. Senyawa lain yang dikandung adalah thymoquinone, dithymouinone, thymohydroquimone, dan thymol yang berfungsi mengaktifkan kekebalan spesifik/kekebalan didapat, karena dapat meningkatkan kadar sel-sel $\mathrm{T}$ pembantu, sel-sel $\mathrm{T}$ penekan, dan sel-sel pembunuh alami Kandungan lainnya yaitu crystalline nigellon dan arginine sebagai stabilisator sistem imunitas tubuh Berdasarkan kelarutannya dalam pelarut, senyawa-senyawa yang terkandung dalam Nigella sativa banyak terlarut dalam etanol. Hal ini menyebabkan potensi ekstrak etanol sebagai agen sitotoksik lebih besar dibandingkan dengan ekstrak eter dan infusa. Di samping itu, karena sitoksisitas ekstrak etanol terhadap sel Vero dibandingkan sel T47 D mempunyai harga yang paling besar maka ekstrak etanol merupakan ekstrak yang lebih potensial untuk dikembang- kan dalam penelitian selanjutnya sebagai antikanker.

\section{KESIMPULAN}

1. Ekstrak Eter, etanol, dan infusa biji $N$. sativa L. (jinten hitam) mempunyai aktivitas sitotoksik terhadap sel T47D dengan harga LC50 berturut-turut sebesar 32,63; 10,02 dan 23,82 $\mu \mathrm{g} / \mathrm{ml}$. Aktivitas sitotoksik terhadap sel Vero dengan harga $\mathrm{LC}_{50}$ berturut-turut sebesar 300,$6 ; 328,41$; dan 778,64 $\mu \mathrm{g} / \mathrm{ml}$.

2. Ekstrak eter, etanol, dan infusa biji $N$. sativa L. (jinten hitam) pada kadar $62,5 \mu \mathrm{g} / \mathrm{ml}$ dan $31,625 \mu \mathrm{g} / \mathrm{ml}$ memiliki aktivitas antiproliferatif terhadap sel T47D dengan memperpanjang harga doubling time.

\section{SARAN}

1. Perlu dilakukan pemisahan kandungan kimia terhadap ekstrak tanol biji $N$. sativa L. (jinten hitam) serta pengujian aktivitas senyawa yang mempunyai aksi penghambatan terhadap sel T47D.

2. Perlu dilakukan penelitian mekanisme molekuler untuk mengkaji mekanisme aksinya. 


\section{UCAPAN TERIMAKASIH}

Kepada Kemenristek atas dana penelitian Riset Insentif Dasar tahun 2009-2010

\section{DAFTAR PUSTAKA}

Ali, B. H., and Blunden, G., 2003, Pharmacological and toxicological properties of Nigella sativa, Phytotherapy Research, 17, (4), 299-305

Doyle, A., and Griffiths, J. B., (2000), Cell and Tissue Culture for Medical Research, British, Wiley.

Duan, R., Ginsburg, E., and Vonderhaar, B. K., 2008, Estrogen stimulates transcription from the human prolactin distal promoter through AP1 and estrogen responsive elements in T47D human breast cancer cells, Molecular and Cellular Endocrinology, 281, (1â€"2), 9-18

Govorkova, E. A., Murti, G., Meignier, B., De Taisne, C., and Webster, R. G., 1996, African green monkey kidney (Vero) cells provide an alternative host cell system for influenza A and B viruses, Journal of virology, 70, (8), 5519-5524

Hanahan, D., and Weinberg, R. A., Hallmarks of cancer: the next generation, Cell, 144, (5), 646-674

Jrah Harzallah, H., Kouidhi, B., Flamini, G., Bakhrouf, A., and Mahjoub, T., 2010, Chemical composition, antimicrobial potential against cariogenic bacteria and cytotoxic activity of Tunisian Nigella sativa essential oil and thymoquinone,
Food Chemistry, 129, (4), 1469-1474

Lombello, C. B., Malmonge, S. M., and Wada, M. L. F., 2000, PolyHEMA and polyHEMA-poly (MMA-co-AA) as substrates for culturing Vero cells, Journal of Materials Science: Materials in Medicine, 11, (9), 541-546

Majdalawieh, A. F., Hmaidan, R., and Carr, R. I., 2010, Nigella sativa modulates splenocyte proliferation, Th1/Th2 cytokine profile, macrophage function and NK anti-tumor activity, Journal of Ethnopharmacology, 131, (2), 268-275

Nasaruddin, N. (2006). Extraction of pharmacologically active thymoquinone in nigella sativa $\mathrm{L}$, Universiti Malaysia Pahang.

Sartorius, C. A., Shen, T., and Horwitz, K. B., 2003, Progesterone receptors $\mathrm{A}$ and $\mathrm{B}$ differentially affect the growth of estrogen-dependent human breast tumor xenografts, Breast cancer research and treatment, 79, (3), 287-299

Scheuer, L., Kauff, N., Robson, M., Kelly, B., Barakat, R., Satagopan, J., Ellis, N., Hensley, M., Boyd, J., and Borgen, P., 2002, Outcome of preventive surgery and screening for breast and ovarian cancer in BRCA mutation carriers, Journal of Clinical Oncology, 20, (5), 1260-1268

Thabrew, M. I., Mitry, R. R., Morsy, M. A., and Hughes, R. D., 2005, Cytotoxic effects of a decoction of 
Nigella sativa, Hemidesmus Zhu, W., Qin, W., and Sauter, E. R., indicus and Smilax glabra on human hepatoma HepG2 cells, Life sciences, 77, (12), 1319-1330 2004, Large-scale mitochondrial DNA deletion mutations and nuclear genome instability in human breast cancer, Cancer Detection and Prevention, 28, (2), $119-126$ 2006, Carcinogen-Induced DNA Double Strand Break Repair in Sporadic Breast Cancer, Journal of Surgical Research, 135, (1), $120-128$ 